\title{
CRIMINAL LEGAL PROTECTION OF CHILD VICTIMS AND WITNESSES OF CRIMES
}

\author{
Monika Mushevska, master student on \\ Faculty of law at the University "Goce Delcev" - Stip, Macedonia \\ monika.071074@student.ugd.edu.mk
}

\begin{abstract}
The term victim indicates a natural person that underwent some kind of crime, including psychological and mental disorder, and emotional suffering or monetary loss, that were caused by accomplishing or not accomplishing a certain kind of activity that violates the law in one state. The term Victim also includes the close members of the victim's family that depend on the victim. "Kids, victims and witnesses of crimes" indicates kids and adolescents under 18 years of age, which are victims of different kinds of crime or witnesses of different kinds of crime, in spite of the role that they have in the crime act. In all proceedings that directly or indirectly child victims involved it is important to act in a way that is the best and most appropriate for the child.
\end{abstract}

Key words: victim, witness, crime, child

\section{Introduction}

All kids, victims and witnesses of crime, have the right to be protected from every kind of discrimination, have the right of special protection for their own safety and also for the safety of their relatives. The Attorney General, the police and the court act with special care and protection for these kids, that are victims or witnesses of crimes and also when deciding to file a lawsuit against the defendant, they take care for the kids and their interests. Towards the kids victims and crime witnesses are taken special measures for trail defense like: hiding kid's identity and aspect, removing the judicial robes and the hats, excluding the public, using special technical facilities for communication and also to protect the privacy of the kid and his family. The procedure for the crime in which the kids are the victims, is urgent. The kids, victims of a crime are being questioned like witnesses in a way that doesn't affect their personal psychophysical development and at the time of the questioning, the court, the police and the Attorney General are obligated to take care of the personal characteristics of the kids. According to the law, the protection for the kids victims and the kids witnesses of crime, is guaranteed with the Children justice law, the Criminal procedure law and the Law on witness protection. The kid victim is the only witness of the crime that is being committed against him. So, in order to capture the criminal, the victim's witnessing cannot be avoided, where the fact itself shows the possibility for causing a trauma because of the revivifying the moment of the crime, which can bring us to victimization of the kid. Our legislative provides special care for kids with several acts: the Child protection law, the Law for criminal procedure and the Law for witness protection. But so far, nothing has changed, there is no international law that refers only to the rights of the kids-victims or witnesses of crime. In all of the cases, when kids are being involved, directly or in an indirect way, the best thing to do is to act in a way that is the best and the most appropriate for the kid. The very notion - a child, points to the fact that children as innocent creatures are often put in situations of sexual, psychological or physical abuse to harassment and violence occur as subjects of criminal offenses and are used to commit various crimes The protection for the kidswitnesses of crime it's not just a protection from some kind of wound or damage, there should also exist some kind of standards that can secure proper and healthy growth of the kid. 


\section{Prevention and protection from domestic violence (domestic abuse)}

The term domestic violence is a specific pattern of behavior which involves torture, humiliation, endangering safety, physical abuse as well as sexual and physical violence which causes a threat, fear, insecurity and other similar activities undertaken by one person against another in the domestic settings including spouses, parents and even children. If there are certain traces of domestic violence, every citizen is obliged to report it to the police center or to the social work center. Child victims and witnesses in the trial should be treated in a caring and compassionate manner taking into account their personal situation and immediate needs, age, gender, disability and maturity and fully respecting their physical, mental and moral integrity. Every child should be treated as a person with their individual needs, desires and feelings.

Every child has the right to be heard and this indicates that his/her attitude and opinion should be taken into account in order to take an active part during the proceedings. The fact is that this requires special measures for protection and support of the child victims and witnesses of crimes, so as to prevent any possible victimization in the process of criminal justice. For these reasons, there is a need of mandatory requirement for expertise in the procedure for those crimes in which children are victims of crimes or victims of violence. $^{1}$

The international standards suggest some certain minimal assurances which by default must exist in each national legislation in order to provide a successful protection of the child victims and child witnesses of crime. The procedures which are made for respecting the basic principles of the children's rights refer first of all, to

\footnotetext{
${ }^{1}$ Marjanovic, F., Kanevchev M. (2010):Macedonian criminal law ,page 154
}

the best interests of the child, than to the non-discrimination, the right to life and the right to participate in the process of decision-making. For the realization of these rights, one needs to create a special environment for conversation with the child victims and also to provide special rooms for their examination thus using special technical means of communication. When making decisions about children, the moto and the fundamental principle that should be followed and respected by all prosecutors, judges, lawyers and medical officers is "The best interest of the child".

The convention on the rights of the child that Republic of Macedonia has ratified consists of taking over the responsibility for managing the protection, achievement and improvement of the rights of the children. The convention on the rights of the child also guarantees that the country will take care of all the necessary measures for the social reintegration of the children, and also will take care of their physical and emotional recovery.

Indisputable is the fact that the participation of all the kids-victims of crimes in the proceedings is very important for the efficiency of the criminal proceedings that include trafficking of children, sexual abuse of children and other forms of organized crimes, where the only witnesses involved are children. In the end, the meaning one human being's existence, his present and also his future is connected to the children they are the reason for a more meaningful life.

Every human being creates his own values, earns his own wealth and property that remains for the next generations and his kids were and always will be his future and the mirror of his existence. The mistakes in the growth of the generations leave marks on the development of our future. Losing our children forever leaves a mark and darkness on our soul. That's why I want to direct our attention on full protection of our children, innocent creatures. The trauma, the emotional or 
physical suffering or some other problems that they get after being witnesses of crime is something that should be the object of a national program, a one for a protection of all those children, because they are our immense treasure. ${ }^{2}$

\subsection{Handling a situation with children that are victims of a crime}

Children can appear victims of crimes in special cases that are included in the Penal code where the victim can be only a minor. Those cases where as victim appears only a minor are the following: sexual assault on a child under the age of 14 , killing a baby in the process of giving a birth, displaying a pornographic material to a minor, leaving a weak person, trafficking of children and a children maltreatment. Protecting the privacy of the child victim and witness is of primary importance. Any information concerning the participation of children in the justice process should be protected. This can be achieved through maintaining confidence and limit the disclosure of information that could lead to the identification of the child victim or witness in the trial. Required to be observed the principle of secrecy that excluding the public and the media from the courtroom during the testimony of the child.

All types of conversation with child victim must be done in special rooms for children. The rooms must be qualified specifically for children with all children claims including children furniture and children toys. In procedures which included child victim, public prosecutor must protect child form additional questioning! If they were questioned from the police in the previous proceedings the children victim can't be questioning again later.

Minor victims of crimes are at least twice victimized. First victimization happens with the actual perpetration of the crime of violence and the negative reaction of the social environment, and secondary,

\footnotetext{
${ }^{2}$ Law of Justice of the Child (Official Newspaper of RM br.148 / 2013)

the criminal procedure conducted because of the crime of violence. Victimization of a minor is a process in which that person becomes the victim of a crime of violence. Such victimization can produce very serious consequences, and some of those consequences are a result of the current structure of the criminal proceedings. The fact is that they require special measures to protect and support child victims and witnesses of crimes in order to prevent any possible victimization in the process of criminal justice. In practice, the number of hearings is not respected leading to further victimization. Secondary victimization of the child in criminal proceedings can be reduced or prevented by avoiding rehearing of the child victim of a crime of violence in a way that again is facing with the accused.

Basically the whole issue boils down to the fact of proving the essential details, while the secondary victimization of the child in the criminal procedure can be reduced or prevented by avoiding rehearing of the child victim of crime or violence his hearing in a manner that the child victim of crime is exposed to the accused person. In terms of evidentiary rules, they must suffer some modification primarily regarding the protection of minor persons - victims. In that sense, legislative reforms allow such evidence to be used by all video and audio files that are recorded testimony of child victims and enabling again the statement of the minor to be used as evidence in other phases of the procedure without his further harassment. However, in reality, lies our frequently occurring situations in which children are victims of crimes are forced to give testimony repeatedly before the start of the trial. In this way this norm remains only in declarative nature. ${ }^{3}$

\footnotetext{
${ }^{3}$ Sayson, Winston L. The Canadian Youth Criminal Justice System Children as Victims (and Witnesses) of Crimes and Children Charged with Crimes, Vancouver: International Centre for Criminal Law Reform and Criminal Justice Policy (ICCLR), December 2006
} 


\section{Children as witnesses in proceeding}

In accordance with the Criminal Procedure, clearly stipulate that witnesses appear only those persons who are aware that they can definitely give proper notification of a crime and the offender. The law stipulates that as witnesses can appear minors as well. Each entity that will be called as a witness is obliged to answer the summons and is obliged to testify unless it is unable to understand the meaning of his right taking into account his age and his mental development. The questions that will be asked of the witness during the proceedings can be set only by the body conducting the proceedings or more specifically, by the public prosecutor, who is obliged towards the minor witness to act with particular care in order to avoid adverse impact on its personality and his mental health. Pursuant to the justice of the children, a child - witness has the same rights as a child - victim and their hearing should be conducted in the same manner.

\section{Conclusion}

Every child must be preparing for living in modern society. They must be raised in the spirit of peace, tolerance, dignity and freedom equality just like is written in Charter of the United Nations! The child must grow up in a happy and harmonious environment, which will be filled with love and happiness and understanding. Conventions, in which children are provided with their personal rights, provide a special opportunity to be questioned in any judicial proceedings that will apply to them, regardless of whether it will be hearing directly (tete a tete) or through their legal representative. In accordance with the law for righteousness to children, efforts are made that no child shall be subjected to torture or other degrading and inhuman actions, so that life imprisonment can't be imposed on persons below 18 years and endeavor, by taking appropriate measures, to influence the social reintegration and social adaptation of children - victims of exploitation, abuse or other forms of inhuman and cruel crimes.

\section{Used literature:}

1. Kambovski V. (2004): Criminal Law General Part, Skopje

2. Marjanovic, F., Kanevchev M. (2010):Macedonian criminal law - general part, Skopje;

3. Sayson, Winston L.(2006) The Canadian Youth Criminal Justice System Children as Victims (and Witnesses) of Crimes and Children Charged with Crimes, Vancouver: International Centre for Criminal Law Reform and Criminal Justice Policy (ICCLR),

4. UN Economic and Social Council 2005/20: Guidelines on Justice in Matters Involving Child Victims and Witnesses of Crime, 22 July 2005, E/RES/2005/20.

5. United Nations Office on Drugs and Crime, Model Law on Justice in Matters involving Child Victims and Witnesses of Crime, UN, New York, 2009;

6. Council of Europe Convention on the Protection of children against sexual exploitation and sexual abuse, 12 July 2007;

7. Directive 2012/29/EU of the European Parliament and of the Council of 25 October 2012 establishing minimum standards on the rights, support and protection of victims of crime, and replacing Council Framework Decision 2001

8. Kambovski, V. (1998): International Criminal Law, Skopje;

9. Law of Justice of the Child (Official Newspaper of RM br.148 / 2013). 